\title{
MAPPING ENTREPRENEURIAL EDUCATION: AN INSTRUMENT FOR INCLUDING YOUNG PEOPLE IN THE ECONOMY
}

\author{
Fernanda De Oliveira Silva ${ }^{1}$, José Salvador da Motta Reis ${ }^{2}$, Maximilian Espuny ${ }^{2}$, Otávio José de Oliveira ${ }^{2}$, \\ Luís César Ferreira Motta Barbosa ${ }^{3}$, Gilberto Santos ${ }^{4^{(*)}}$ \\ ${ }^{1}$ UFABC, Universidade Federal do ABC, São Bernardo do Campo, Brazil \\ ${ }^{2}$ FEG/UNESP, Universidade Estadual Paulista, Fac. de Engenharia de Guaratinguetá, Guaratinguetá, Brazil \\ ${ }^{3}$ CEFET/RJ, Federal Center for Technological Education Celso Suckow da Fonseca, Rio de Janeiro, Brazil \\ ${ }^{4}$ IPCA, School of Design of the Polytechnic Institute of Cávado and Ave, Barcelos, Portugal \\ ${ }^{(*)}$ Email: gsantos@ipca.pt
}

\begin{abstract}
Entrepreneurial education is a considerable tool to reduce young people's dependence on the labour market and insert them into the formal economy. It is observed that there is a significant increase in both supply and demand for vocational courses. To identify the main elements of this field, we researched the terms "entrepreneurial education" in the title and keywords and 716 articles were obtained. The field of study has a considerable increase in recent years, and the European continent stands out considerably compared to all others.
\end{abstract}

Keywords: entrepreneurial education, entrepreneurship, formal economy, inclusion of young people.

\section{INTRODUCTION}

In times of crisis, the emergence of new ventures is seen as an alternative for the resumption of economic growth, since entrepreneurship brings technological innovation and job creation for society (Sánchez, 2013). The entrepreneur is identified as the agent who decides to start a new business from the breakdown of a paradigm by inserting a new product or service in the market (O'Connor, 2013). It is estimated that four million new annual jobs are generated worldwide through new businesses (Rideout and Gray, 2013). In this way, entrepreneurship ends up being incorporated into the political agenda of some nations, becoming part of central public policies (O'Connor, 2013). Thus, it is observed that there is a growth in the supply and demand of courses focused on Entrepreneurial Education (Martin et al., 2013; Rideout and Gray, 2013). This tool offering is seen as an alternative capable of fostering business activity (O'Connor, 2013). The objective of this article is to identify the state of the art of Entrepreneurial Education. In order to achieve this proposition, a bibliometric study was developed, with the purpose of identifying the evolution of scientific productions, authors, journals, countries and keywords for the identification of the main approaches on the theme currently held.

\section{RESULTS AND CONCLUSIONS}

To obtain the results, the historical series of publications regarding entrepreneurial education from 2013 to November 2019 was verified, with the perspective of seeing whether an evolution of interest was presented in this period by researchers. We sought the articles that presented the words "entrepreneurial education" in the title or keywords elected by the authors and a total of 716 documents were obtained in English. It was found that since 2015 there has been a steady 
increase in publications in the theme, as can be seen in Figure 1. For the analysis of the main authors, journals and authors who publish on entrepreneurial education, we chose to hierarchize the information through the H-Index of each of the analyzed elements, so that the number of documents could be contradicted with the number of citations submitted by each of them.

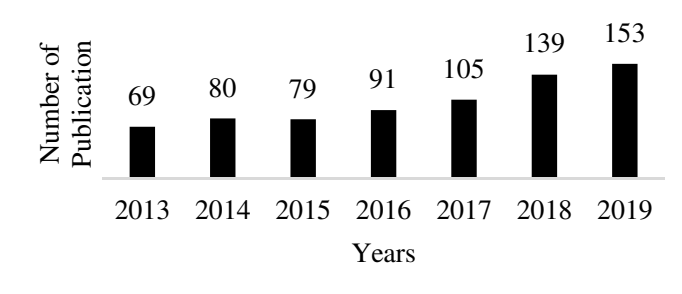

Fig. 1 - Evolution of Entrepreneurial Education publications

Among the most expressive authors in entrepreneurial education are Ruskovaara (Finland, HIndex 5), Fayolle (France, H-Index 4) and Lans (Netherlands, H-Index 4). All main authors have an average of at least 15 citations per document. In relation to journals, we highlight the journals Education and Training (H-Index 17), Journal of Small Business Management (HIndex 12) and International Journal of Management Education (H-Index 11). The three journals obtained at least five publications in 2019, with an average of at least nine article citations and have the number of citations in continuous growth from 2016 to 2019. In relation to the countries with higher H-Index publications focused on entrepreneurial education, the United States, the United Kingdom (with respective H-Index 17) and Sweden (H-Index 12) are presented. With the exception of the United States and Australia, all other countries are European (including Finland, Norway, Germany and Portugal), which allows a reflection on how this knowledge is concentrated and has the need to be sprayed on other continents, especially among the poorest such as Latin America, Africa and Asia. The keywords that were used most in this theme were: "entrepreneurial Intention" (46) and "higher education" (45) and "student" (37). The words "education" and "entrepreneurship" were excluded because they are the main descriptors of this study.

There is the potential for increased these studies through the evolution of publications, since the unemployment among young people in different regions of the world is greater than the average number of unemployed people, including all age groups.

\section{REFERENCES}

[1] Martin BC, McNally JJ, Kay MJ (2013), Examining the formation of human capital in entrepreneurship: A meta-analysis of entrepreneurship education outcomes. J Bus Ventur 28; pp.211-224; doi: 10.1016/j.jbusvent.2012.03.002.

[2] O'Connor A (2013), A conceptual framework for entrepreneurship education policy: Meeting government and economic purposes. J Bus Ventur 28, pp.546-563, doi: 10.1016/j.jbusvent.2012.07.003.

[3] Rideout EC, Gray DO (2013), Does Entrepreneurship Education Really Work? A Review and Methodological Critique of the Empirical Literature on the Effects of University-Based Entrepreneurship Education. J Small Bus Manag 51, pp.329-351, doi: 10.1111/jsbm.12021.

[4] Sánchez JC (2013), The Impact of an Entrepreneurship Education Program on Entrepreneurial Competencies and Intention. J Small Bus Manag 51, pp.447-465, doi: $10.1111 /$ jsbm. 12025 . 